This item was submitted to Loughborough's Research Repository by the author.

Items in Figshare are protected by copyright, with all rights reserved, unless otherwise indicated.

\title{
Greenhouse gas and noxious emissions from dual fuel diesel and natural gas heavy goods vehicles
}

\section{PLEASE CITE THE PUBLISHED VERSION}

https://doi.org/10.1021/acs.est.5b04240

\section{PUBLISHER}

American Chemical Society (ACS)

\section{VERSION}

VoR (Version of Record)

\section{PUBLISHER STATEMENT}

This is an Open Access Article. It is published by American Chemical Society under the Creative Commons Attribution 4.0 Unported Licence (CC BY). Full details of this licence are available at: http://creativecommons.org/licenses/by/4.0/

\section{LICENCE}

CC BY 4.0

\section{REPOSITORY RECORD}

Stettler, Marc EJ, Will Midgley, Jacob J Swanson, David Cebon, and Adam M Boies. 2016. "Greenhouse Gas and Noxious Emissions from Dual Fuel Diesel and Natural Gas Heavy Goods Vehicles". Loughborough University. https://hdl.handle.net/2134/13655705.v1. 


\title{
Greenhouse Gas and Noxious Emissions from Dual Fuel Diesel and Natural Gas Heavy Goods Vehicles
}

\author{
Marc E. J. Stettler, ${ }^{*}{ }^{\dagger}$, William J. B. Midgley, ${ }^{\dagger}$ Jacob J. Swanson, ${ }^{\S}$ David Cebon, ${ }^{\dagger}$ and Adam M. Boies ${ }^{\dagger}$ \\ ${ }^{\dagger}$ Centre for Sustainable Road Freight, Department of Engineering, University of Cambridge, Cambridge, CB2 1PZ, U.K. \\ ${ }^{\ddagger}$ Centre for Transport Studies, Department of Civil and Environmental Engineering, Imperial College London, London SW7 2AZ, \\ U.K. \\ ${ }^{\S}$ Minnesota State University Mankato, Mankato, Minnesota 56001, United States
}

\section{Supporting Information}

ABSTRACT: Dual fuel diesel and natural gas heavy goods vehicles (HGVs) operate on a combination of the two fuels simultaneously. By substituting diesel for natural gas, vehicle operators can benefit from reduced fuel costs and as natural gas has a lower $\mathrm{CO}_{2}$ intensity compared to diesel, dual fuel HGVs have the potential to reduce greenhouse gas (GHG) emissions from the freight sector. In this study, energy consumption, greenhouse gas and noxious emissions for five after-market dual fuel configurations of two vehicle platforms are compared relative to their diesel-only baseline values over transient and steady state testing. Over a transient cycle, $\mathrm{CO}_{2}$ emissions are reduced by up to $9 \%$; however, methane $\left(\mathrm{CH}_{4}\right)$ emissions due to incomplete combustion lead to $\mathrm{CO}_{2} \mathrm{e}$ emissions that are 50-127\% higher than the equivalent diesel vehicle. Oxidation catalysts evaluated on the vehicles at steady state reduced $\mathrm{CH}_{4}$ emissions by at most $15 \%$ at exhaust gas temperatures representative of transient conditions. This study highlights that control of $\mathrm{CH}_{4}$ emissions and improved control of in-cylinder $\mathrm{CH}_{4}$ combustion are required to reduce total GHG emissions of dual fuel HGVs relative to diesel vehicles.

\section{INTRODUCTION}

1.1. Context. Globally, road freight transport is responsible for around a quarter of transport energy use. ${ }^{1}$ In the UK, heavy goods vehicles (HGVs) involved in freight movements account for $22 \%$ and $23 \%$ of road transport energy use ${ }^{2}$ and greenhouse gas (GHG) emissions ${ }^{3}$ respectively. Long haul and regional duty cycles account for approximately $70 \%$ of UK $\mathrm{HGV} \mathrm{CO}_{2}$ emissions and the substitution of natural gas (NG) for diesel has the potential to reduce $\mathrm{HGV} \mathrm{CO}_{2}$ emissions due to the lower $\mathrm{CO}_{2}$ intensity of methane compared to diesel. ${ }^{4}$ In 2012, the UK Technology Strategy Board and the Office for Low Emission Vehicles provided $£ 11.3 \mathrm{~m}(\sim \$ 17.5 \mathrm{~m})$ to trials of 362 diesel-NG dual fuel trucks, using five different dual fuel systems. Four out of five of these systems are aftermarket conversions, whereas one is supplied by an original equipment manufacturer (OEM). ${ }^{5}$ In 2013, the European Commission provided $€ 14.3 \mathrm{~m}$ $(\sim 15.6 \mathrm{~m})$ to the trial of $100 \mathrm{LNG}$ HGVs, including dual fuel vehicles. ${ }^{6}$ In the US, the Environmental Protection Agency has certified one diesel-NG conversion system for new engines, which grants exemption from the Clean Air Act tampering prohibition, and a number of other dual fuel systems for intermediate age engines. ${ }^{7}$

The use of $\mathrm{NG}$ as a transport fuel is at least partially motivated by the potential to reduce $\mathrm{CO}_{2}$ emissions. The primary component of NG is methane $\left(\mathrm{CH}_{4}\right)$. As $\mathrm{CH}_{4}$ has a

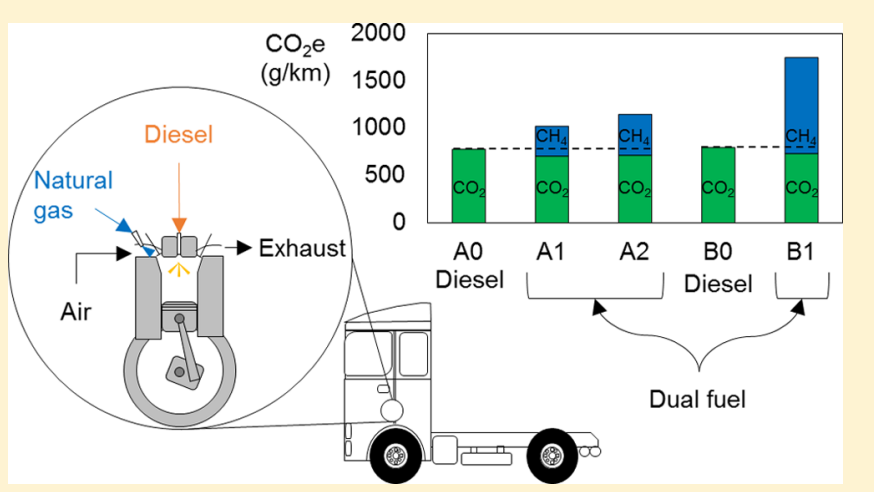

higher ratio of hydrogen to carbon atoms (4:1) than diesel $(\sim 2: 1)$, less $\mathrm{CO}_{2}$ is emitted per unit of chemical energy released by combustion. A dual fuel engine is a conventional compression ignition diesel engine in which a significant proportion of the energy released by combustion is derived from the combustion of a gaseous fuel, such as NG. ${ }^{8}$ All of the dual fuel systems installed on vehicles residing the UK operate by injecting NG into the intake air prior to the intake valves so that a NG-air mixture is drawn into the combustion chamber. ${ }^{5,9-12}$ This NG-air charge is then ignited by an injection of diesel at the end of the compression stroke, which has a shorter ignition delay than the NG. ${ }^{8}$ This dual fuel concept differs from systems that employ high-pressure direct injection (HPDI) of NG into the combustion chamber. ${ }^{13}$

Dual fuel engines offer an attractive alternative to other engine technologies due to the (i) higher thermal efficiency relative to spark-ignited engines, (ii) flexible fuel capability with the option to operate solely on diesel when gaseous fuel is not available, (iii) reduced fuel costs, and (iv) reductions in emissions of $\mathrm{CO}_{2}$ and other engine exhaust components. ${ }^{4,14}$

Received: September 1, 2015

Revised: January 5, 2016

Accepted: January 12, 2016

Published: January 12, 2016 
Table 1. Test Vehicle Specifications and List of Transient Test Parameters

\begin{tabular}{l}
\multicolumn{1}{c}{ base vehicle } \\
EURO V $4 \times 2$ tractor \\
max power: $228 \mathrm{~kW}$ \\
max torque: $1275 \mathrm{Nm}$ \\
engine displacement: $9.2 \mathrm{~L}$ \\
compression ratio: 17.4 \\
bore/stroke: $118 / 140 \mathrm{~mm}$ \\
wheelbase: $3.6 \mathrm{~m}$ \\
EURO V $6 \times 2$ tractor \\
max power: $295 \mathrm{~kW}$ \\
max torque: $2000 \mathrm{Nm}$ \\
engine displacement: $11.97 \mathrm{~L}$ \\
compression ratio: 18.5 \\
bore/stroke: $128 / 155 \mathrm{~mm}$ \\
wheelbase: $3.9 \mathrm{~m}$
\end{tabular}

$\begin{array}{llcc}\text { ref } & \text { after-treatment } & \text { fuel } & \text { hot/cold start } \\ \text { A0 } & \text { SCR } & \text { diesel } & \text { hot } \\ \text { A1 } & \text { SCR } & \text { dual fuel } & \text { hot } \\ \text { A2 } & \text { SCR and oxi cat } & \text { dual fuel } & \text { hot } \\ \text { A3 } & \text { SCR } & \text { dual fuel } & \text { cold } \\ \text { A4 } & \text { SCR and oxi cat } & \text { dual fuel } & \text { cold }\end{array}$

Previous studies of dual fuel engine emissions have focused on engine dynamometer testing, rather than full vehicle emissions testing. These studies have shown significant changes to emissions when compared to conventional diesel engines. $^{8,14-21}$ Dual fuel engine emissions depend on a number of parameters including the engine speed, engine load, the composition and quantity of primary gaseous fuel, the quantity of pilot diesel, the temperature of the intake primary fuel and air mixture, the pilot injection timing and stratification of the gaseous fuel and air mixture. ${ }^{16,21-23}$ In previous studies, dual fuel combustion with NG as the primary fuel led to reduced emissions of oxides of nitrogen $\left(\mathrm{NO}_{x}\right)$ but increased emissions of carbon monoxide (CO) and unburnt hydrocarbons (HC) ${ }^{14-21}$ The majority of the unburnt hydrocarbon emissions from a NG dual fuel engines is $\mathrm{CH}_{4}$ and the magnitude of these emissions depended strongly on the concentration of the gaseous fuel in the cylinder. ${ }^{14,18}$ Using a global warming potential (GWP) of 25 for $\mathrm{CH}_{4}$, Besch et al. ${ }^{18}$ showed that while $\mathrm{CO}_{2}$ emissions were reduced by $3-8 \%$ for three dual fuel engines relative to diesel operation over the heavy duty engine Federal Test Procedure, emissions of $\mathrm{CH}_{4}$ led to $18-129 \%$ increases in $\mathrm{CO}_{2} \mathrm{e}$ emissions.

Previous smoke opacity measurements have shown that diesel and NG dual fuel combustion has the potential to reduce smoke emissions. ${ }^{19,20,24}$ Graves et al. ${ }^{25}$ characterized the morphology and volatility of particles emitted by an HPDI dual fuel engine, however this is a distinctly different dual fuel concept from that employed by the systems currently in use and evaluated in this study.

1.2. Overview. This paper presents an evaluation of transient and steady state energy use, GHG, $\mathrm{NO}_{x}, \mathrm{CO}$, and particulate matter (PM) emissions of five vehicle configurations of two dual fuel aftermarket conversion systems that account for the majority $(\sim 60 \%)$ of the 362 trialled dual fuel vehicles in the $\mathrm{UK}^{5}$ In contrast to previous studies that have tested engines installed on engine dynamometers, ${ }^{21}$ this study tests inuse vehicles with emissions control devices on a chassis dynamometer to quantify dual fuel HGV emissions factors for subsequent use in environmental impact assessments and to provide emissions metrics that are relevant to policy makers and logistics fleet operators. Furthermore, this paper highlights areas for technology development. Due to commercial sensitivities, the vehicle owners and the dual fuel conversion suppliers have not been disclosed.

\section{MATERIALS AND METHODS}

2.1. Outline of Study. The vehicle configurations and specifications of the original vehicle platforms are summarized in Table 1 . This study's authors did not modify or attempt to control the performance of the dual fuel systems or fuelling strategies. On both vehicles where methane oxidation catalysts are present, these were installed upstream of the OEM selective catalytic reduction (SCR) unit by the dual fuel conversion suppliers. The dosing of aqueous urea solution in the SCR systems on both vehicles was not altered and neither vehicle was fitted with a diesel particulate filter. Configurations A0 $(4 \times$ 2 tractor $)$ and B0 $(6 \times 2$ tractor $)$ are taken as baseline tests, while $\mathrm{A} 1$ and $\mathrm{B} 1$ are the most common diesel-NG dual fuel vehicle configurations for suppliers A and B respectively. The configuration in $\mathrm{A} 2$ and $\mathrm{A} 4$ is unique for this study and is not a standard option offered by supplier A; it was tested to evaluate the impact of an oxidation catalyst on performance and emissions. This oxidation catalyst was a prototype design that was installed immediately before these emissions tests were conducted. In contrast, the oxidation catalyst on vehicle B had been installed on the vehicle for approximately $500000 \mathrm{~km}$ and is therefore is representative of catalysts in operation. Transient cycle and steady state vehicle emissions testing was conducted on a $1.22 \mathrm{~m}$ (42 in.) single roll chassis dynamometer capable of simulating 20 tonnes of inertia (Millbrook Proving Ground Ltd., Bedford, MK45 2JQ UK). Further experimental details including fuel properties and uncertainty analyses are shown in the Supporting Information.

2.2. Test Cycles. Transient cycle emissions were obtained over the vehicle version of the European Transient Cycle, developed by the FIGE Institute. ${ }^{26}$ The FIGE cycle has three distinct phases, representing urban (U), rural (R), and motorway (M) driving. Hot start tests followed a consistent engine warm up procedure, while cold start tests were conducted at $0{ }^{\circ} \mathrm{C}$ after the vehicle had been soaked overnight. Steady state emissions testing on the chassis dynamometer was conducted to develop a map of engine emissions as a function of engine torque and speed (revolutions per minute, rpm) that would also be of further use in vehicle emissions models. ${ }^{27}$ Engine speed and torque were systematically varied in $\sim 200$ rpm and $\sim 200 \mathrm{~N}$ m steps, respectively. Each test point was held for at least $2 \mathrm{~min}$, consistent with regulatory engine test cycles. $^{28,29}$ 
Table 2. Energy Consumption, Energy Substitution Ratio, $\mathrm{CO}_{2}$ and $\mathrm{CO}_{2} \mathrm{e}$ Emissions Factors from Transient Testing ${ }^{a}$

\begin{tabular}{|c|c|c|c|c|c|c|c|c|c|c|c|c|c|c|c|c|}
\hline \multirow[b]{2}{*}{ ref } & \multicolumn{4}{|c|}{ energy $(\mathrm{MJ} / \mathrm{km})$} & \multicolumn{4}{|c|}{ ESR (\%) } & \multicolumn{4}{|c|}{$\mathrm{CO}_{2}(\mathrm{~g} / \mathrm{km})$} & \multicolumn{4}{|c|}{$\mathrm{CO}_{2} \mathrm{e}(\mathrm{g} / \mathrm{km})$} \\
\hline & $\mathrm{U}$ & $\mathrm{R}$ & $\mathrm{M}$ & $\mathrm{C}$ & $\mathrm{U}$ & $\mathrm{R}$ & $\mathrm{M}$ & C & $\mathrm{U}$ & $\mathrm{R}$ & M & $\mathrm{C}$ & $\mathrm{U}$ & $\mathrm{R}$ & $\mathrm{M}$ & $\mathrm{C}$ \\
\hline A0 & 12.8 & 10.2 & 10.5 & 10.7 & 0 & 0 & 0 & 0 & 957 & 753 & 747 & 777 & 954 & 751 & 740 & 772 \\
\hline A1 & 13.7 & 11.1 & 12.3 & 12.0 & 37.6 & 45.9 & 58.3 & 50.9 & 923 & 686 & 662 & 705 & 1264 & 931 & 1055 & 1036 \\
\hline A2 & 12.5 & 10.4 & 11.6 & 11.3 & 31.0 & 37.1 & 51.4 & 43.4 & 920 & 708 & 663 & 714 & 1344 & 1013 & 1239 & 1168 \\
\hline A3 & 16.7 & 11.5 & 12.3 & 12.6 & 16.5 & 46.8 & 59.3 & 49.1 & 1175 & 711 & 676 & 753 & 1305 & 952 & 1083 & 1062 \\
\hline A4 & 13.1 & 12.1 & 12.6 & 12.5 & 5.4 & 37.3 & 48.7 & 40.0 & 1184 & 724 & 673 & 744 & 1269 & 1089 & 1352 & 1242 \\
\hline B0 & 14.6 & 10.1 & 11.0 & 11.2 & 0 & 0 & 0 & 0 & 1135 & 754 & 742 & 798 & 1129 & 758 & 748 & 801 \\
\hline B1 & 20.4 & 9.9 & 11.9 & 12.2 & 32.7 & 53.6 & 73.5 & 60.7 & 1156 & 692 & 649 & 730 & 2522 & 1408 & 1945 & 1817 \\
\hline B2 & 15.7 & 13.3 & 14.3 & 14.1 & 0.9 & 54.0 & 71.1 & 57.4 & 1443 & 703 & 650 & 751 & 1380 & 1550 & 2418 & 1977 \\
\hline
\end{tabular}

Table 3. $\mathrm{NO}_{x}, \mathrm{CH}_{4}, \mathrm{PM}$, and PN Emissions from Transient Testing ${ }^{a}$

\begin{tabular}{|c|c|c|c|c|c|c|c|c|c|c|c|c|c|c|c|c|}
\hline \multirow[b]{2}{*}{ ref } & \multicolumn{4}{|c|}{$\mathrm{NO}_{x}(\mathrm{~g} / \mathrm{km})$} & \multicolumn{4}{|c|}{$\mathrm{CH}_{4}(\mathrm{~g} / \mathrm{km})$} & \multicolumn{4}{|c|}{ PM mass $(\mathrm{mg} / \mathrm{km})$} & \multicolumn{4}{|c|}{$\mathrm{PN}\left(\times 10^{14} \# / \mathrm{km}\right)$} \\
\hline & $\mathrm{U}$ & $\mathrm{R}$ & $\mathrm{M}$ & $\mathrm{C}$ & $\mathrm{U}$ & $\mathrm{R}$ & $\mathrm{M}$ & $\mathrm{C}$ & $\mathrm{U}$ & $\mathrm{R}$ & $\mathrm{M}$ & C & $\mathrm{U}$ & $\mathrm{R}$ & $\mathrm{M}$ & $\mathrm{C}$ \\
\hline A0 & 7.8 & 4.4 & 4.0 & 4.6 & 0.0 & 0.0 & 0.0 & 0.0 & 54.5 & 26.8 & 19.5 & 26.8 & 1.66 & 0.84 & 0.72 & 0.89 \\
\hline A1 & 7.4 & 3.6 & 1.9 & 3.3 & 8.5 & 6.5 & 11.4 & 9.2 & 77.8 & 48.3 & 13.8 & 35.1 & 1.89 & 1.10 & 0.43 & 0.87 \\
\hline $\mathrm{A} 2$ & 10.2 & 4.4 & 2.0 & 4.0 & 11.5 & 8.3 & 16.5 & 12.8 & 89.0 & 54.5 & 24.6 & 44.2 & 2.31 & 1.47 & 0.79 & 1.24 \\
\hline A3 & 12.3 & 4.4 & 2.1 & 4.2 & 3.9 & 6.6 & 11.8 & 8.8 & 29.4 & 36.3 & 12.7 & 23.7 & 0.61 & 0.85 & 0.37 & 0.58 \\
\hline A4 & 14.3 & 5.3 & 2.6 & 4.8 & 2.3 & 10.5 & 19.8 & 14.4 & 76.2 & 33.6 & 13.8 & 27.7 & 2.12 & 0.93 & 0.51 & 0.83 \\
\hline B0 & 7.3 & 1.0 & 0.3 & 1.5 & 0.0 & 0.0 & 0.0 & 0.0 & 28.7 & 10.7 & 6.9 & 11.2 & 0.99 & 0.28 & 0.22 & 0.34 \\
\hline B1 & 2.4 & 0.9 & 2.3 & 1.8 & 38.9 & 18.9 & 35.6 & 29.7 & 40.4 & 13.9 & 8.5 & 14.7 & 1.38 & 0.31 & 0.25 & 0.42 \\
\hline B2 & 19.7 & 2.8 & 2.6 & 4.4 & 0.1 & 24.7 & 45.8 & 33.0 & 13.0 & 6.3 & 5.1 & 6.3 & 0.38 & 0.14 & 0.15 & 0.17 \\
\hline
\end{tabular}

${ }^{a} \mathrm{U}=$ urban, $\mathrm{R}=$ rural, $\mathrm{M}=$ motorway, $\mathrm{C}=$ combined phases of the FIGE cycle.

2.3. Instrumentation. The net flow rate of diesel supplied to the engines was measured using an FMS MK10 fuel flowmeter (JPS Engineering, UK), which recorded flow in $5 \mathrm{~mL}$ increments. The mass flow rate of NG delivered to the engines was measured by a Rotamass RCCS34 Coriolis flow meter (Yokogawa Electric Corporation, Japan) placed in line between the low pressure regulator and gas injectors of the dual fuel systems. This Coriolis flow meter was sized to minimize interference with dual fuel system by minimizing pressure drop while maintaining accuracy; at a nominal flow rate of $22.5 \mathrm{~kg}$ / hour at 5 bar and $20{ }^{\circ} \mathrm{C}$, the pressure drop and accuracy were calculated to be $17 \mathrm{mbar}$ and $1.1 \%$ respectively. The energy substitution ratio (ESR) is defined as the proportion of total energy supplied to the engine in the form of NG,

$$
\operatorname{ESR}[\%]=\frac{\dot{m}_{\mathrm{NG}, \text { in }} \mathrm{LCV}_{\mathrm{NG}}}{\dot{m}_{\mathrm{NG}, \text { in }} \mathrm{LCV}_{\mathrm{NG}}+\dot{m}_{\text {diesel,in }} \mathrm{LCV}_{\text {diesel }}} \times 100
$$

where $\dot{m}_{\mathrm{NG} \text {,in }}$ and $\dot{m}_{\text {diesel,in }}$ are the mass flow rates of NG and diesel supplied to the engine respectively, and LCV is the lower calorific value of the fuel.

Engine emissions and exhaust gas temperatures were measured at two locations in the exhaust; (i) post-turbo (PT), equivalent to an engine-out measurement, and (ii) at the tailpipe. A complete list of the emissions analysers and emissions species is included in the SI. Reported emissions factors have been calculated based on the modal $1 \mathrm{~Hz}$ data for transient and steady state testing. For $\mathrm{CO}_{2}, \mathrm{NO}_{x}$ and $\mathrm{CO}$, these emissions factors were within $1 \%, 1 \%$, and $7 \%$ of emissions factors calculated based on averaged bag measurements over the entire transient test cycle, respectively.

$\mathrm{CH}_{4}$ emissions were measured at the post-turbo and tailpipe locations using Fourier Transform Infra-Red (FTIR) spectrometers (Multigas 2030 and 2030 HS respectively, MKS Instruments, $\mathrm{MA}$ ). $\mathrm{CH}_{4}$ slip is reported as the ratio of the mass flow rate of exhausted $\mathrm{CH}_{4}, \dot{m}_{\mathrm{CH}_{4} \text {,tailpipe }}$ to the mass flow rate of $\mathrm{CH}_{4}$ supplied to the engine in the NG, $\dot{m}_{\mathrm{CH}_{4}, \mathrm{in}}$,

$$
\mathrm{CH}_{4} \operatorname{slip}[\%]=\frac{\dot{m}_{\mathrm{CH}_{4} \text { tailpipe }}}{\dot{m}_{\mathrm{CH}_{4}, \text { in }}} \times 100 \%
$$

The effectiveness of oxidation catalysts in the vehicles' exhaust after-treatment systems was evaluated by comparing $\mathrm{CH}_{4}$ concentrations at the post-turbo and tailpipe sampling points measured by the two FTIR instruments.

A DMS500 (Cambustion Ltd., UK) measured real-time particle size distributions at the tailpipe. PM and black carbon (BC) mass emissions were estimated using the integrated particle size distribution (IPSD) method. ${ }^{30,31}$ The aggregate effective density, $\rho_{\text {eff }}$ as a function of mobility diameter, $d_{\mathrm{p}}$, was calculated as

$$
\rho_{\text {eff }}=\rho_{0}\left(\frac{d_{\mathrm{p}}}{d_{\mathrm{pp}}}\right)^{D_{\mathrm{m}}}
$$

where $\rho_{0}$ is the material density, $d_{\mathrm{pp}}$ is the primary particle diameter and $D_{\mathrm{m}}$ is the mass-mobility exponent with assumed values of $2 \mathrm{~g} / \mathrm{cm}^{3}, 16 \mathrm{~nm}$ and 2.35 respectively. ${ }^{32}$ For $d_{\mathrm{p}}$ less than $30 \mathrm{~nm}$, an effective density of $1.46 \mathrm{~g} / \mathrm{cm}^{3}$ is assumed. ${ }^{32}$ Total PM mass was calculated by integrating over the entire size distribution $(5-1000 \mathrm{~nm})$, while for $\mathrm{BC}$, a log-normal distribution was fitted to the accumulation mode. Reported particle number (PN) emissions factors are calculated by summing the product of the particle size distribution and a detection efficiency curve ${ }^{33}$ fitted to data for condensation particle counters with detection efficiencies of $50 \%$ at $23 \mathrm{~nm}^{34}$ This enables comparison to measurements following the solid particle number measurement protocol developed through the Particle Measurement Programme (PMP). ${ }^{35}$ 
Total GHG emissions, as $\mathrm{CO}_{2} \mathrm{e}$ were calculated by summing $\mathrm{CO}_{2}, \mathrm{CH}_{4}, \mathrm{~N}_{2} \mathrm{O}, \mathrm{NO}_{x}, \mathrm{CO}$, and $\mathrm{BC}$ emissions multiplied by their GWPs for a time horizon of 100 years. GWPs for $\mathrm{CH}_{4}$ (34) and $\mathrm{N}_{2} \mathrm{O}$ (298) are taken from the IPCC's Fifth Assessment Report (AR5) and include climate-carbon feedbacks. ${ }^{36}$ All GWPs are included in the SI and we note that choosing a shorter time horizon (e.g., 20 years) would increase the importance of short-lived species (e.g., $\mathrm{CH}_{4}$ ).

\section{RESULTS}

3.1. Transient Cycle Energy Consumption and Emissions. Distance specific energy consumption and emissions factors over different phases of the FIGE cycle ( $U$ = urban, $\mathrm{R}=$ rural, $\mathrm{M}=$ motorway, $\mathrm{C}=$ combined) for the different vehicle configurations are shown in Table 2 and Table 3. This data is shown graphically in the SI. Distance specific energy consumption is generally highest during the urban phase, followed by the motorway and rural phases for all vehicle configurations. In general, dual fuel operation reduces energy efficiency and results in higher total energy consumption compared to the baseline diesel only tests (A0 and $\mathrm{B} 0$ ). For A1 and B1, combined cycle energy consumption was $12 \%$ and $10 \%$ higher than the equivalent diesel tests. Previous studies have also shown that energy efficiency of dual fuel engines are reduced compared to diesel at low and intermediate engine loads, which is attributed to lower combustion efficiency of the lean NG-air charge mixture and higher rates of heat loss during combustion. ${ }^{21}$ Over the four dual fuel tests with vehicle A, higher ESR during $\mathrm{A} 1$ and $\mathrm{A} 3$ compared to $\mathrm{A} 2$ and $\mathrm{A} 4$, indicates that the dual fuel system supplier may have updated their control software. Comparing A1 to A2, higher ESR is correlated with higher energy consumption yet lower $\mathrm{CO}_{2}$ emissions. For vehicles $\mathrm{A}$ and $\mathrm{B}$, the highest ESR is observed during the motorway phase and during this phase, the $\mathrm{CO}_{2}$ emissions factor is lowest and the relative reduction compared to diesel is greatest at up to $11 \%$ and $13 \%$ for $\mathrm{A} 1$ and $\mathrm{B} 1$ respectively. For context, the fuel properties (shown in the SI) indicate that complete combustion of NG would emit approximately $21 \%$ less $\mathrm{CO}_{2}$ per unit of energy than diesel used in this study, assuming no change in energy efficiency. For the cold start tests, (A3, A4, and B2), distance specific energy consumption and emissions of $\mathrm{CO}_{2}$ were generally greater than the equivalent hot start test. Both dual fuel conversion suppliers account for engine temperature in their control of the ESR; during the urban phase, when engine temperatures are cold, the ESR is significantly reduced relative to the same phase in hot start tests.

$\mathrm{CO}_{2}$ and $\mathrm{CH}_{4}$ (shown in Table 3) dominated total $\mathrm{CO}_{2} \mathrm{e}$ emissions and capture the first-order climate impacts of dual fuel relative to diesel. The combined cycle relative contribution of $\mathrm{CH}_{4}$ normalized to the $\mathrm{CO}_{2}$ contribution was between $40 \%$ for $\mathrm{A} 3$ and $150 \%$ for $\mathrm{B} 2 . \mathrm{CH}_{4}$ emissions factors were highest during the motorway phase, which is also the phase with highest ESR. For all dual fuel tests on both vehicles, $\mathrm{CH}_{4}$ emissions led to increased $\mathrm{CO}_{2} \mathrm{e}$ emissions relative to the diesel baseline tests. Comparing $\mathrm{Al}$ to $\mathrm{A} 0$ and $\mathrm{B} 1$ to $\mathrm{B} 0$, dual fuel operation increased $\mathrm{CO}_{2} \mathrm{e}$ emissions factors by $32 \%, 24 \%, 42 \%$ and $123 \%, 86 \%, 160 \%$ for the urban, rural, and motorway phases, respectively. Therefore, it is clear that $\mathrm{CH}_{4}$ emissions outweigh potential reductions in $\mathrm{CO}_{2}$ emissions that result from substituting diesel for NG. For A1, 8.4\%, 6.5\%, and 8.1\%, and for $\mathrm{B} 1,30.1 \%, 18.4 \%$, and $21.0 \%$ of $\mathrm{CH}_{4}$ that was delivered to the engine was emitted to the atmosphere during the urban, rural and motorway phases, respectively. These findings are in agreement with previous engine dynamometer testing of dual fuel retrofit systems, which also measured significant increases in $\mathrm{CO}_{2} \mathrm{e}$ emissions due to $\mathrm{CH}_{4}$ emissions. ${ }^{18}$ The addition of an oxidation catalyst to $\mathrm{A} 2$ compared to $\mathrm{A} 1$ did not significantly reduce $\mathrm{CH}_{4}$ emissions; indeed distance specific $\mathrm{CH}_{4}$ emissions increased, which could be indicative of an altered fuelling strategy or that backpressure due to the oxidation catalyst may have had an adverse effect on in-cylinder combustion and therefore engine emissions performance. Oxidation catalyst effectiveness is discussed further in Section 3.3.

The combined cycle relative contributions of all species to $\mathrm{CO}_{2} \mathrm{e}$ emissions are shown in the SI. For the dual fuel tests on vehicle $\mathrm{B}$, the next largest contributor was $\mathrm{N}_{2} \mathrm{O}$ emissions with $10 \%$ and $16 \%$ of the $\mathrm{CO}_{2}$ contribution for tests $\mathrm{B} 1$ and $\mathrm{B} 2$ respectively. Measured $\mathrm{N}_{2} \mathrm{O}$ emissions for these tests were significantly higher than for B0 or for any of the tests with vehicle $\mathrm{A}$. Tailpipe $\mathrm{NO}_{x}$ emissions during the motorway phase of B1 were significantly increased compared to B0. This is despite post-turbo $\mathrm{NO}_{x}$ emissions being approximately halved in B1 compared to B0 over the same phase (shown in the SI). For vehicle $\mathrm{A}$ dual fuel tests, post-turbo $\mathrm{NO}_{x}$ emissions were reduced by $\sim 40 \%$ and tailpipe $\mathrm{NO}_{x}$ by $\sim 50 \%$ during the motorway phase compared to the baseline A0. For A1, postturbo and tailpipe $\mathrm{NO}_{x}$ emissions were reduced by $30 \%$ compared to diesel over the combined cycle. Post-turbo $\mathrm{NO}_{2} /$ $\mathrm{NO}_{x}$ ratios were also different for dual fuel compared to diesel; for $\mathrm{A} 1$ this ratio was 0.34 over the combined cycle compared to 0.06 for A0 (shown in the SI). After the SCR, $\mathrm{NO}_{2} / \mathrm{NO}_{x}$ ratios decreased to 0.15 for $\mathrm{A} 1$ and increased to 0.22 for $\mathrm{A} 0$. Indeed at the tailpipe, dual fuel $\mathrm{NO}_{2} / \mathrm{NO}_{x}$ ratios are generally lower than for the diesel tests for both vehicles A and B. Performance of the SCR systems over the combined cycle reduced from $43 \%$ to $34-41 \%$ comparing $\mathrm{A} 0$ to $\mathrm{A} 1$ and $\mathrm{A} 2$, and $83 \%$ to $67 \%$ comparing $\mathrm{B} 0$ to $\mathrm{B} 1$. These results indicate that dual fuel operation affects the efficacy of the OEM SCR systems.

Particle mass and particle number emissions in warm start dual fuel tests were higher than the baseline diesel tests. The distance averaged particle size distributions (i.e., weighted by exhaust volumetric flow and divided by cycle distance) are shown in Figure 1. Bimodal distributions are present for all tests. Comparing $\mathrm{A} 1$ to $\mathrm{A} 0$, the $\mathrm{PM}$ mass emissions factor is

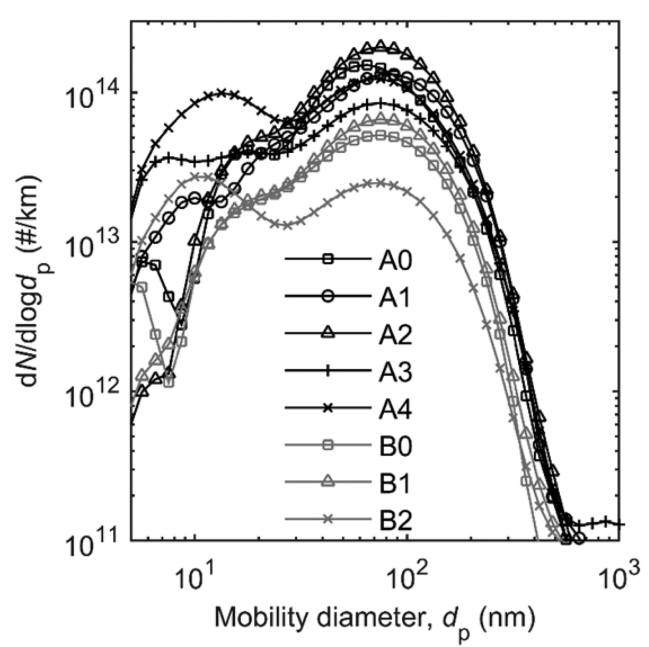

Figure 1. Distance specific particle size distributions over the combined FIGE cycle. 
increased by $\sim 30 \%$ due to a shift in the accumulation mode peak diameter from $\sim 65 \mathrm{~nm}$ to $\sim 85 \mathrm{~nm}$ with total particle number emissions approximately equivalent. The peak of the accumulation mode for vehicle $\mathrm{B}$ is not shifted significantly between $\mathrm{B} 0$ and $\mathrm{B} 1$, however the $\mathrm{PN}$ emissions are increased by $\sim 20 \%$ leading to a $\sim 30 \%$ increase in total PM mass. Cold start tests led to a more significant nucleation mode peaks and reduced accumulation mode peaks relative to equivalent hot start tests. The contribution of $\mathrm{BC}$ mass to $\mathrm{CO}_{2} \mathrm{e}$ emissions as a percentage of the $\mathrm{CO}_{2}$ contribution is between 1.8 and $4.3 \%$ for vehicle $A$ and $0.5-1.3 \%$ for vehicle $B$ relative to $\mathrm{CO}_{2}$. $\mathrm{BC}$ mass contributed between 60 and $80 \%$ of total PM mass, across all transient tests, as shown in the SI along with uncertainties on the particle size distributions. Steady state PM mass emissions for vehicle A are discussed further in the following section.

Engine power specific emissions factors for vehicle A over the combined FIGE/ETC cycle are shown in the SI and compared to EURO $\mathrm{V}$ regulatory values for engine dynamometer tests over the equivalent cycle. ${ }^{28}$ The baseline A0 configuration was compliant with $\mathrm{CO}$ and PM mass standards, however $\mathrm{NO}_{x}$ emissions were $\sim 2.5$ times higher than the standard $(2.0 \mathrm{~g} / \mathrm{kWh})$. Indeed, $\mathrm{NO}_{x}$ emissions were higher than the EURO $\mathrm{V}$ standard for all vehicle A configurations. Dual fuel operation led to increased $\mathrm{CO}$ emissions for $\mathrm{A} 1$, however the oxidation catalyst on configuration $\mathrm{A} 2$ meant $\mathrm{CO}$ emissions were equal to those of $\mathrm{A} 0 . \mathrm{CH}_{4}$ emissions, which are only regulated for NG engines at type-approval, ${ }^{28}$ were 8.9 times higher than the regulatory limit value $(1.1 \mathrm{~g} / \mathrm{kWh})$ for the Al configuration of this aftermarket dual fuel system.

3.2. Steady State Emissions. Steady state maps of ESR and $\mathrm{CH}_{4}$ slip for $\mathrm{Al}$, and the ratio of dual fuel to diesel (A1:A0) $\mathrm{CO}_{2}$ and $\mathrm{CO}_{2} \mathrm{e}$ emissions as a function of engine speed and torque are shown in Figure 2. For A1, the ESR reaches $~ 70 \%$ for engine speeds between 1200 and $1600 \mathrm{rpm}$ and relatively low engine torque around $\sim 300 \mathrm{~N} \mathrm{~m}$. At higher engine torque output and engine speeds, the ESR is reduced (as controlled by the system supplier's own proprietary software); at $600 \mathrm{~N} \mathrm{~m}$, the ESR is between 50 and $60 \%$ for the $1200-1600 \mathrm{rpm}$ range. This can be cross referenced to the average ESR over the motorway phase of the transient cycle measured to be $58 \%$ for $\mathrm{A} 1$, during which the average engine torque and speed were approximately $600 \mathrm{~N} \mathrm{~m}$ and $1400 \mathrm{rpm}$, respectively. $\mathrm{CH}_{4}$ slip is greatest at higher engine speeds, indicating that incomplete combustion of $\mathrm{CH}_{4}$ is most significant when the in-cylinder residence time is lowest. The ratio of $\mathrm{CO}_{2}$ emissions for $\mathrm{Al}$ versus $\mathrm{A} 0$ indicates that the greatest reduction in $\mathrm{CO}_{2}$ emissions is around $15 \%$ and that this occurs for engine speeds between 1000 and $1600 \mathrm{rpm}$ and engine torque between 300 and $500 \mathrm{~N} \mathrm{~m}$. This corresponds to areas of high ESR (50$70 \%)$ and lower engine speeds. However, as shown for the transient cycle emissions, $\mathrm{CH}_{4}$ emissions for $\mathrm{Al}$ lead to higher total $\mathrm{CO}_{2} \mathrm{e}$ emissions over almost the entire map compared to $\mathrm{A} 0$; this ratio is highest at low engine torques and higher engine speeds.

Further evidence of incomplete combustion of $\mathrm{CH}_{4}$ at higher engine speeds is provided in Figure 3, which shows the dual fuel to diesel (A1:A0) ratio of post-turbo $\mathrm{NO}_{x}$ and $\mathrm{CO}$ emissions and exhaust temperature. Dual fuel $\mathrm{NO}_{x}$ emissions are lower than diesel over most of the map, however the greatest reductions are observed for engine speeds greater than $\sim 1800 \mathrm{rpm}$ indicating lower average in-cylinder temperatures. This is further supported by the map of post-turbo exhaust temperatures which are generally lower for A1 than A0 for

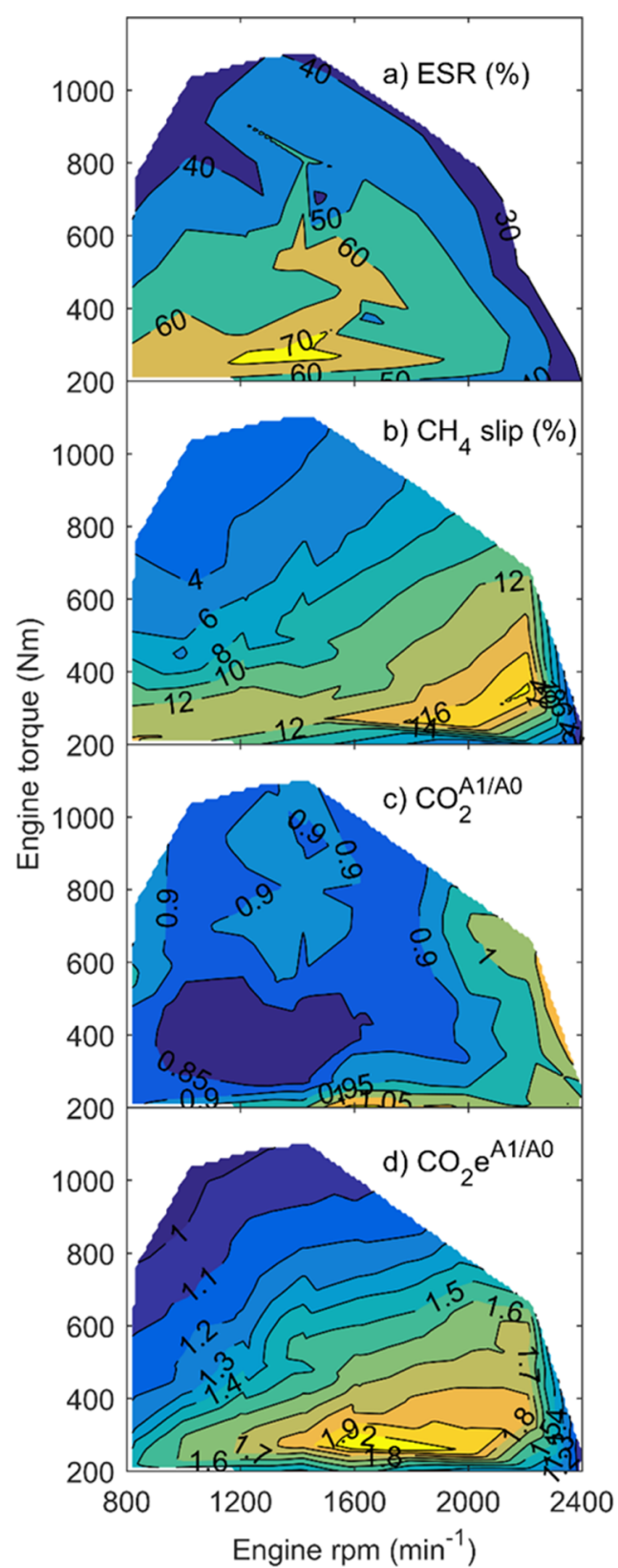

Figure 2. (a) Energy substitution ratio (ESR) of $\mathrm{Al}$, (b) $\mathrm{CH}_{4}$ slip of $\mathrm{A1}$, (c) ratio of $\mathrm{CO}_{2}$ emissions for $\mathrm{Al}: \mathrm{A0}$, and (d) ratio of $\mathrm{CO}_{2} \mathrm{e}$ emissions for A1:A0 all as a function of engine speed and torque as measured during steady state testing of vehicle A.

engine speeds greater than $\sim 1800 \mathrm{rpm}$ and engine torque greater than $\sim 400 \mathrm{~N} \mathrm{~m}$. Post-turbo $\mathrm{CO}$ emissions, a product of incomplete combustion, are greater across the entire map for A1 compared to A0, and at high engine speeds they are increased by an order of magnitude.

Steady state PM mass emissions are shown in Figure 3 as a ratio of those measured for configurations $\mathrm{A} 1$ and $\mathrm{A} 0$. In the previous section, we showed that PM mass emissions increased for the dual fuel transient cycle tests compared to diesel. In Figure 3, it is evident that PM mass emissions are up to $50 \%$ lower for A1 compared to A0 at engine loads below $600 \mathrm{~N} \mathrm{~m}$ and engine speeds below $2000 \mathrm{rpm}$. However, at engine loads greater than $600 \mathrm{~N} \mathrm{~m}$ and engine speeds less than $1500 \mathrm{rpm}$, $\mathrm{PM}$ mass emissions are increased for Al compared to A0 by up to a factor of 3 . 


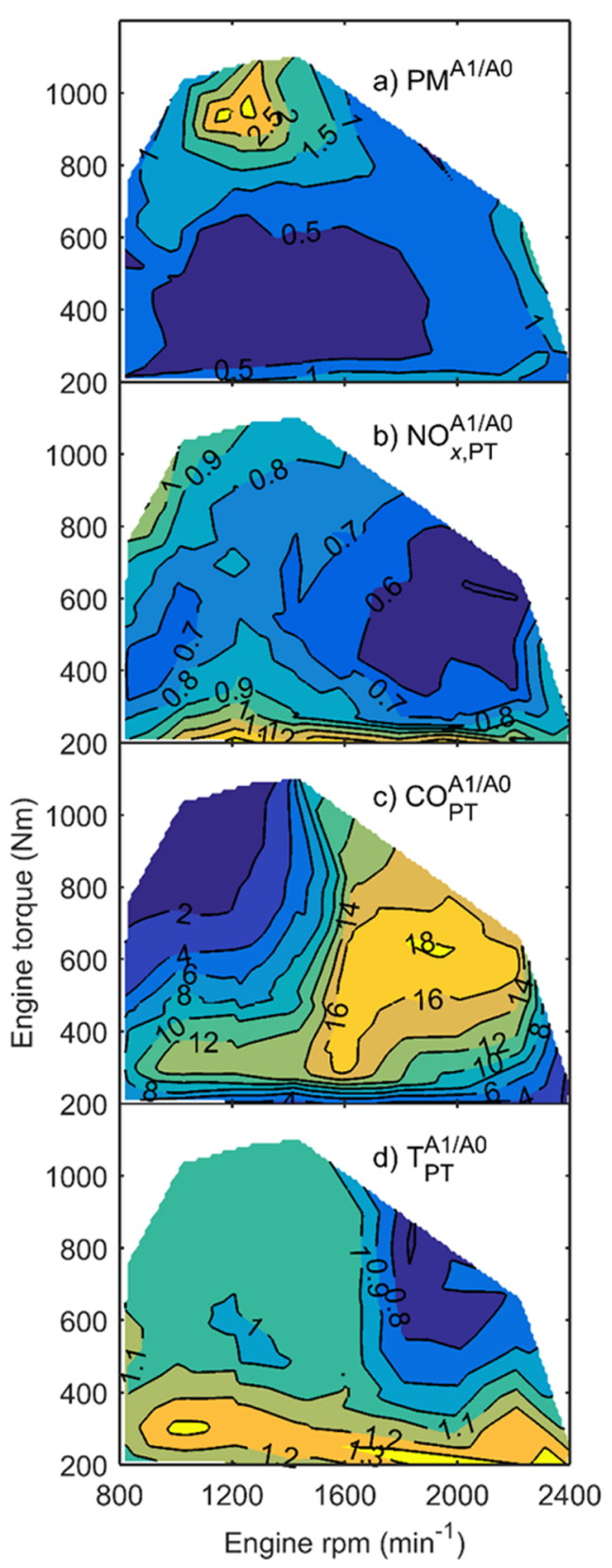

Figure 3. Ratios of (a) tailpipe PM mass emissions, (b) post-turbo (PT) $\mathrm{NO}_{x}$ emissions, (c) PT CO emissions, and (d) PT exhaust temperature as a function of engine speed and torque measured during steady state testing of vehicles A1 and A0.

3.3. Oxidation Catalyst Effectiveness. The effectiveness of the oxidation catalysts fitted to vehicles $\mathrm{A} 2$ and $\mathrm{B} 1$ during steady state testing is shown in Figure 4 . The catalyzed oxidation of $\mathrm{CH}_{4}$ is a function of both residence time within the catalyst and exhaust gas temperature. ${ }^{37}$ The measured catalyst effectiveness was greatest at high temperatures and residence times, that is, low exhaust flow rates. For A2, the highest observed catalyst efficiency was $27 \%$ for a post-turbo exhaust temperature of $470{ }^{\circ} \mathrm{C}$ and exhaust volumetric flow rate of 0.07 $\mathrm{m}^{3} / \mathrm{s}$. For B1, the highest observed catalyst efficiency was $30 \%$ for a post-turbo exhaust temperature of $505{ }^{\circ} \mathrm{C}$ and exhaust volumetric flow rate of $0.10 \mathrm{~m}^{3} / \mathrm{s}$. For context, the average post-turbo exhaust temperatures and exhaust gas flow rates during the motorway phase of the transient cycle test were 396 ${ }^{\circ} \mathrm{C}$ and $0.14 \mathrm{~m}^{3} / \mathrm{s}$ for $\mathrm{A} 2$ and $370{ }^{\circ} \mathrm{C}$ and $0.16 \mathrm{~m}^{3} / \mathrm{s}$ for B1.

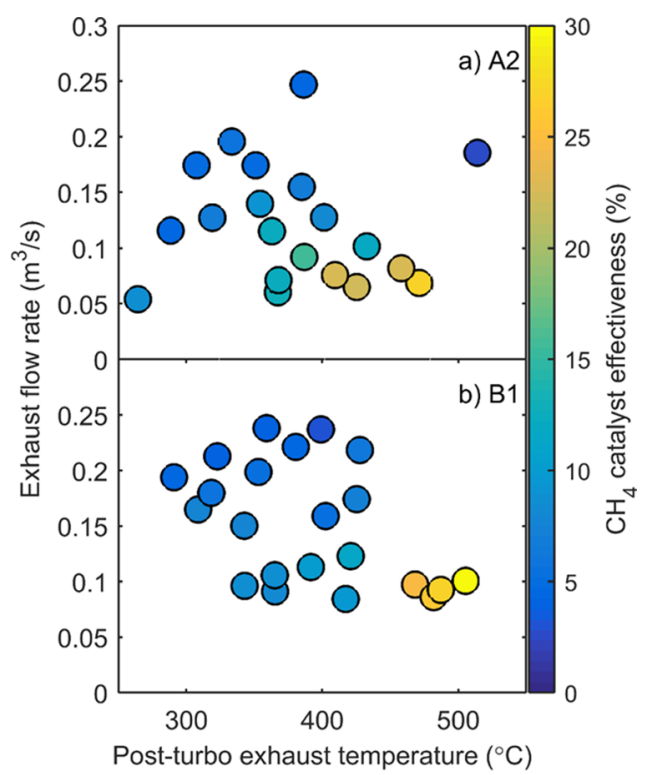

Figure 4. $\mathrm{CH}_{4}$ oxidation efficiency of the catalyst present on (a) vehicle $\mathrm{A} 2$ and (b) B1 as a function of exhaust flow rate and post-turbo exhaust temperature as measured during steady state testing.

These flow rates correspond to gas hourly space velocities of approximately $190000 \mathrm{~h}^{-1}$ and $76000 \mathrm{~h}^{-1}$ for the oxidation catalysts on A and B respectively. Below $400{ }^{\circ} \mathrm{C}$, the maximum performance of these catalysts were $15 \%$ and $10 \%$ for $\mathrm{A} 2$ and $\mathrm{B} 1$, respectively, and therefore these results support the transient emissions results presented above that highlighted the significant contribution of tailpipe $\mathrm{CH}_{4}$ to $\mathrm{CO}_{2} \mathrm{e}$ emissions.

A benefit of the oxidation catalysts is to oxidize increased $\mathrm{CO}$ emissions during dual fuel operation to $\mathrm{CO}_{2}$. Post-turbo and tailpipe $\mathrm{CO}$ emissions factors are shown in the SI. Even without the $\mathrm{CH}_{4}$ oxidation catalyst, $\mathrm{CO}$ emissions are reduced by $72 \%$, $81 \%$, and $76 \%$ by the SCR system for vehicles $\mathrm{A} 0, \mathrm{Al}$, and $\mathrm{A} 3$ respectively. However, with the $\mathrm{CH}_{4}$ oxidation catalyst, $\mathrm{CO}$ emissions are reduced by $94 \%$ and $92 \%$ for A2 and A4 respectively. Similarly, CO emissions were reduced by $95 \%$, $93 \%$, and $97 \%$ for tests B0, B1, and B2 respectively.

\section{DISCUSSION}

This study evaluated the emissions performance of two vehicle platforms with five aftermarket dual fuel system configurations via chassis dynamometer testing of in-use vehicles that are part of trials of low-carbon trucks in the UK. Both dual fuel systems evaluated in this study increased tailpipe total GHG $\left(\mathrm{CO}_{2} \mathrm{e}\right)$ emissions compared to their equivalent diesel vehicles; by $50 \%$ and $127 \%$ over the combined FIGE cycle for configurations A1 and $\mathrm{B} 1$ respectively. This is despite $\mathrm{CO}_{2}$ emissions being reduced by up to $\sim 9 \%$ and is primarily a result of incomplete combustion of $\mathrm{CH}_{4}$ and subsequent $\mathrm{CH}_{4}$ emissions, termed $\mathrm{CH}_{4}$ slip. The three main mechanisms of $\mathrm{CH}_{4}$ slip are (i) valve overlap which causes a proportion of the NG-air charge to be directly exhausted, (ii) incomplete combustion due to crevices and flame quenching at the walls of the cylinder, and (iii) incomplete combustion due to lean NG-air mixtures and incylinder temperatures which prevent the flame from propagating throughout the charge. ${ }^{21,38}$ Evidence for incomplete combustion and lower in-cylinder temperatures was provided by post-turbo emissions measurements showing higher $\mathrm{CO}$ and lower $\mathrm{NO}_{x}$ respectively at steady state conditions, especially at 
higher engine speeds when in-cylinder residence times are reduced. The results of this in-use vehicle emissions study are consistent with and supplement a large number of engine emissions studies showing that $\mathrm{NO}_{x}$ emissions decrease and $\mathrm{CO}$ emissions increase with dual fuel combustion relative to diesel. Thus, refinement of dual fuel systems to reduce $\mathrm{CH}_{4}$ slip by addressing these three mechanisms and to improve $\mathrm{CH}_{4}$ combustion efficiency are required. Our results suggests that reducing ESR at high engine speeds could have a beneficial effect on total $\mathrm{CO}_{2} \mathrm{e}$ emissions and the magnitude of this effect over a transient drive cycle should be the topic of further modeling or experimental studies. Another strategy might be to increase the diesel pilot quantity and advance the pilot injection timing, ${ }^{23}$ however trade-offs are increased $\mathrm{NO}_{x}$ emissions and lower ESR and therefore a reduced $\mathrm{CO}_{2}$ benefit compared to diesel combustion. Direct $\mathrm{CH}_{4}$ injection and stratification of the NG within the cylinder may also have the potential to reduce dual fuel $\mathrm{CH}_{4}$ emissions.

$\mathrm{CH}_{4}$ slip can also be controlled by exhaust after-treatment, however the oxidation catalysts tested in this study reduced $\mathrm{CH}_{4}$ emissions by at most $15 \%$ at exhaust gas temperatures representative of transient conditions $\left(\sim 400{ }^{\circ} \mathrm{C}\right)$. Thus, the commercial development of effective catalysts (e.g., Cargnello et al. ${ }^{39}$ ) that successfully oxidize $\mathrm{CH}_{4}$ below $400{ }^{\circ} \mathrm{C}$ are critical to the exploitation of $\mathrm{NG}$ as a transport fuel to reduce GHG emissions.

Both dual fuel platforms had higher PM mass emissions than their equivalent diesel configurations in transient testing. Steady state testing revealed that PM mass emissions were up to three times higher for dual fuel compared to diesel at high engine loads. While the majority of previous studies report decreases in PM mass emissions for dual fuel compared to diesel combustion, ${ }^{21}$ Papagiannakis et al. $^{40}$ reported an increase in soot opacity at high engine loads (80\%) and ESR in the range of $30-50 \%$. It is possible that this phenomena occurs due to the greater likelihood of rich combustion as a result of high diesel and NG flow rates during high engine load conditions. PM mass emissions were up to 50\% lower at low engine loads, which is more consistent with existing literature and is attributable to the lower sooting tendency of premixed combustion of $\mathrm{CH}_{4}$ compared to diffusion mode combustion of diesel. $^{21}$

Results for tailpipe $\mathrm{NO}_{x}$ emissions suggest that the change in exhaust gas composition in dual fuel operation could interfere with the efficacy of the OEM SCR system, which is optimized for diesel operation. Post-turbo and tailpipe exhaust gas temperatures (shown in the SI) are generally higher in the transient dual fuel tests compared to diesel, which may result from heat release via combustion of unburned hydrocarbons over the oxidation catalyst. At higher exhaust gas temperatures and higher $\mathrm{NO}_{2} / \mathrm{NO}_{x}$ ratios the conditions in the SCR may be significantly different when the trucks are in dual fuel mode compared to diesel, thus affecting its performance. ${ }^{41}$ Higher $\mathrm{N}_{2} \mathrm{O}$ emissions for the dual fuel tests compared to diesel tests could be due to (i) higher rates of oxidation of ammonia to $\mathrm{N}_{2} \mathrm{O}$ by $\mathrm{NO}_{2}$ potentially caused by higher $\mathrm{NO}_{2} / \mathrm{NO}_{x}$ ratios at temperatures up to $350{ }^{\circ} \mathrm{C}$, ${ }^{42}$ (ii) direct oxidation of ammonia by oxygen to $\mathrm{N}_{2} \mathrm{O}$ at temperatures above $350{ }^{\circ} \mathrm{C}_{4}^{43}$ or (iii) by thermal decomposition of ammonium nitrate. ${ }^{44,45}$

\section{ASSOCIATED CONTENT}

\section{Supporting Information}

The Supporting Information is available free of charge on the ACS Publications website at DOI: 10.1021/acs.est.5b04240.

Additional details describing experimental methods, supplemental results and an uncertainty analysis (PDF) Data underlying this article available here and can also be accessed on Zenodo at http://dx.doi.org/10.5281/ zenodo.45025 and used under the Creative Commons Attribution license. (ZIP)

\section{AUTHOR INFORMATION}

\section{Corresponding Author}

*Phone: +44 (0) 207594 2094; fax: +44 (0) 207594 6102; email: m.stettler@imperial.ac.uk.

\section{Notes}

The authors declare no competing financial interest.

\section{ACKNOWLEDGMENTS}

We acknowledge support from the UK Engineering and Physical Sciences Research Council (EP/K00915X/1), the UK Department for Transport, the Office for Low Emission Vehicles and Innovate UK (project reference: 400266) and the industrial partners of the Centre for Sustainable Road Freight.

\section{NOMENCLATURE}

\begin{tabular}{|c|c|}
\hline$\rho_{0}$ & material density $\left(\mathrm{g} / \mathrm{cm}^{3}\right)$ \\
\hline$\rho_{\text {eff }}$ & effective density $\left(\mathrm{g} / \mathrm{cm}^{3}\right)$ \\
\hline AR4 & IPCC's Fourth Assessment Report \\
\hline AR5 & IPCC's Fifth Assessment Report \\
\hline $\mathrm{BC}$ & black carbon \\
\hline $\mathrm{C}$ & combined phases of FIGE drive-cycle \\
\hline $\mathrm{CO}_{2} \mathrm{e}$ & carbon dioxide equivalent \\
\hline$D_{\mathrm{m}}$ & mass-mobility exponent \\
\hline$d_{\mathrm{p}}$ & particle mobility diameter $(\mathrm{nm})$ \\
\hline$d_{\mathrm{pp}}$ & primary particle diameter $(\mathrm{nm})$ \\
\hline ESR & energy substitution ratio (\%) \\
\hline ETC & $\begin{array}{l}\text { european transient cycle developed by the FIGE } \\
\text { institute }\end{array}$ \\
\hline FTIR & Fourier Transform Infrared Spectroscopy \\
\hline GHG & greenhouse gas \\
\hline GWP & global warming potential \\
\hline $\mathrm{HC}$ & unburned hydrocarbons \\
\hline HGV & heavy goods vehicle \\
\hline HPDI & high-pressure direct injection \\
\hline IPSD & integrated particle size distribution \\
\hline $\mathrm{LCV}$ & lower (net) calorific value \\
\hline LNG & liquefied natural gas \\
\hline M & motorway (highway) phase of FIGE drive-cycle \\
\hline$\dot{m}_{\mathrm{CH}_{4}, \mathrm{in}}$ & mass flow rate of $\mathrm{CH}_{4}$ supplied to the engine $(\mathrm{kg} / \mathrm{s})$ \\
\hline$\dot{m}_{\mathrm{CH}_{4}, \text { tailpipe }}$ & $\begin{array}{l}\text { mass flow rate of } \mathrm{CH}_{4} \text { exhausted at the tailpipe }(\mathrm{kg} / \\
\text { s) }\end{array}$ \\
\hline$\dot{m}_{\text {diesel,in }}$ & $\begin{array}{l}\text { mass flow rate of diesel supplied to the engine }(\mathrm{kg} / \\
\mathrm{s})\end{array}$ \\
\hline$\dot{m}_{\mathrm{NG}, \text { in }}$ & $\begin{array}{l}\text { mass flow rate of natural gas supplied to the engine } \\
(\mathrm{kg} / \mathrm{s})\end{array}$ \\
\hline NG & natural gas \\
\hline OEM & original equipment manufacturer \\
\hline PM & particulate matter \\
\hline PMP & Particle Measurement Programme \\
\hline $\mathrm{PN}$ & particle number \\
\hline
\end{tabular}


PT post-turbo (emissions sampling point)

$\mathrm{U}$ urban phase of FIGE drive-cycle

$\mathrm{R}$ rural phase of FIGE drive-cycle

rpm revolutions per minute

SCR selective catalytic reduction

$\mathrm{T}$ temperature $\left({ }^{\circ} \mathrm{C}\right)$

\section{REFERENCES}

(1) International Energy Agency. Energy Technology Perspectives 2012. Pathways to a Clean Energy System., 2nd ed.; IEA Publications: Paris, France, 2012.

(2) Department of Energy \& Climate Change. Energy Consumption in the UK (ECUK) Transport data tables 2015 Update https://www. gov.uk/government/statistics/energy-consumption-in-the-uk (accessed Aug 6, 2015).

(3) Department of Energy \& Climate Change. Final UK greenhouse gas emissions national statistics: 1990-2013 https://www.gov.uk/ government/statistics/final-uk-emissions-estimates (accessed August $6,2015)$

(4) Ricardo-AEA. Opportunities to Overcome the Barriers to Uptake of Low Emission Technologies for Each Commercial Vehicle Duty Cycle; London, UK, 2012.

(5) Atkins - Cenex. Low Carbon Truck and Refuelling Infrastructure Demonstration Trial Evaluation. Second Annual Report to the DfT. Executive Summary for publication.; 2015.

(6) European Commission. European Commission: CORDIS: Projects \& Results Service: LNG-BC: Liquefied Natural Gas Blue Corridors http://cordis.europa.eu/project/rcn/198035_en.html (accessed August 6, 2015).

(7) U.S. EPA. Alternative Fuel Conversion http://www.epa.gov/ otaq/consumer/fuels/altfuels/altfuels.htm\#4 (accessed August 6, 2015).

(8) Karim, G. A. A review of combustion processes in the dual fuel engine-The gas diesel engine. Prog. Energy Combust. Sci. 1980, 6 (3), 277-285.

(9) Souto, J.; Ferrera, M.; Leclerq, N.; Matchett, M.; Magnusson, I. LNG Blue Corridors: LNG Trucks Euro $V$ technical solutions; GC.SST.2012.2-3 GA No. 321592, 2014.

(10) Volvo Trucks. Volvo FM MethaneDiesel http://www. volvotrucks.com/trucks/global/en-gb/trucks/new-trucks/Pages/ volvo-fm-methanediesel.aspx (accessed Juen 3, 2015).

(11) Prins Autogas UK Ltd. Prins Autogas UK: Dieselblend System http://www.prinsautogasuk.co.uk/dieselblend.php (accessed Juen 3, 2015).

(12) Clean Air Power. Clean Air Power: How it works http://www. cleanairpower.com/howitworks.html (accessed June 3, 2015).

(13) McTaggart-Cowan, G. P.; Bushe, W. K.; Hill, P. G.; Munshi, S. R. A supercharged heavy-duty diesel single-cylinder research engine for high-pressure direct injection of natural gas. Int. J. Engine Res. 2003, 4 (4), 315-330.

(14) Karim, G. A. Combustion in Gas Fueled Compression: Ignition Engines of the Dual Fuel Type. J. Eng. Gas Turbines Power 2003, 125 (3), 827.

(15) Stewart, J.; Clarke, A.; Chen, R. An experimental study of the dual-fuel performance of a small compression ignition diesel engine operating with three gaseous fuels. Proc. Inst. Mech. Eng., Part D 2007, 221 (8), 943-956.

(16) Polk, A. C.; Gibson, C. M.; Shoemaker, N. T.; Srinivasan, K. K.; Krishnan, S. R. Detailed characterization of diesel-ignited propane and methane dual-fuel combustion in a turbocharged direct-injection diesel engine. Proc. Inst. Mech. Eng., Part D 2013, 227 (9), 1255-1272.

(17) Gatts, T.; Liu, S.; Liew, C.; Ralston, B.; Bell, C.; Li, H. An experimental investigation of incomplete combustion of gaseous fuels of a heavy-duty diesel engine supplemented with hydrogen and natural gas. Int. J. Hydrogen Energy 2012, 37 (9), 7848-7859.

(18) Besch, M. C.; Israel, J.; Thiruvengadam, A.; Kappanna, H.; Carder, D. Emissions Characterization from Different Technology
Heavy-Duty Engines Retrofitted for CNG/Diesel Dual-Fuel Operation. SAE Int. J. Engines 2015, 8 (3), 2015-01-1085.

(19) Papagiannakis, R. G.; Rakopoulos, C. D.; Hountalas, D. T.; Rakopoulos, D. C. Emission characteristics of high speed, dual fuel, compression ignition engine operating in a wide range of natural gas/ diesel fuel proportions. Fuel 2010, 89 (7), 1397-1406.

(20) Papagiannakis, R. G.; Hountalas, D. T. Combustion and exhaust emission characteristics of a dual fuel compression ignition engine operated with pilot Diesel fuel and natural gas. Energy Convers. Manage. 2004, 45 (18-19), 2971-2987.

(21) Wei, L.; Geng, P. A review on natural gas/diesel dual fuel combustion, emissions and performance. Fuel Process. Technol. 2016, 142, 264-278.

(22) Rimmer, J. E.; Johnson, S. L.; Clarke, A. An experimental study into the effect of the pilot injection timing on the performance and emissions of a high-speed common-rail dual-fuel engine. Proc. Inst. Mech. Eng., Part D 2014, 228 (8), 929-942.

(23) Sun, L.; Liu, Y.; Zeng, K.; Yang, R.; Hang, Z. Combustion performance and stability of a dual-fuel diesel-natural-gas engine. Proc. Inst. Mech. Eng., Part D 2015, 229 (2), 235-246.

(24) Gatts, T.; Liu, S.; Liew, C.; Ralston, B.; Bell, C.; Li, H. An experimental investigation of incomplete combustion of gaseous fuels of a heavy-duty diesel engine supplemented with hydrogen and natural gas. Int. J. Hydrogen Energy 2012, 37 (9), 7848-7859.

(25) Graves, B.; Olfert, J.; Patychuk, B.; Dastanpour, R.; Rogak, S. Characterization of Particulate Matter Morphology and Volatility from a Compression-Ignition Natural-Gas Direct-Injection Engine. Aerosol Sci. Technol. 2015, 49 (8), 589-598.

(26) Barlow, T. J.; Latham, S.; McCrae, I. S.; Boulter, P. G. A reference book of driving cycles for use in the measurement of road vehicle emissions 2009.

(27) Hunt, S. W.; Odhams, A. M. C.; Roebuck, R. L.; Cebon, D. Parameter measurement for heavy-vehicle fuel consumption modelling. Proc. Inst. Mech. Eng., Part D 2011, 225 (5), 567-589.

(28) European Union. Directive 1999/96/EC of the European Parliament and of the Council of 13 December 1999 on the approximation of the laws of the Member States relating to measures to be taken against the emission of gaseous pollutants from positive ignition engines fuelled; Official Journal of the European Communities L 44, 1999; p L 44/1L 44/155.

(29) United Nations Economic Commission for Europe (UNECE). Global technical regulation No. 4. Test procedure for compression ignition (C.I.) engines and positive ignition (P.I.) engines fuelled with natural gas $(N G)$ or liquefied petroleum gas (LPG) with regard to the emission of pollutants; ECE/TRANS/180/Add.4, 2007.

(30) Maricq, M. M.; Xu, N. The effective density and fractal dimension of soot particles from premixed flames and motor vehicle exhaust. J. Aerosol Sci. 2004, 35 (10), 1251-1274.

(31) Liu, Z. G.; Vasys, V. N.; Dettmann, M. E.; Schauer, J. J.; Kittelson, D. B.; Swanson, J. Comparison of Strategies for the Measurement of Mass Emissions from Diesel Engines Emitting UltraLow Levels of Particulate Matter. Aerosol Sci. Technol. 2009, 43 (11), $1142-1152$.

(32) Zheng, Z.; Durbin, T. D.; Xue, J.; Johnson, K. C.; Li, Y.; Hu, S.; Huai, T.; Ayala, A.; Kittelson, D. B.; Jung, H. S. Comparison of particle mass and solid particle number (SPN) emissions from a heavy-duty diesel vehicle under on-road driving conditions and a standard testing cycle. Environ. Sci. Technol. 2014, 48 (3), 1779-1786.

(33) Mertes, S.; Schröder, F.; Wiedensohler, A. The Particle Detection Efficiency Curve of the TSI-3010 CPC as a Function of the Temperature Difference between Saturator and Condenser. Aerosol Sci. Technol. 1995, 23 (2), 257-261.

(34) Giechaskiel, B.; Wang, X.; Horn, H.-G.; Spielvogel, J.; Gerhart, C.; Southgate, J.; Jing, L.; Kasper, M.; Drossinos, Y.; Krasenbrink, A. Calibration of Condensation Particle Counters for Legislated Vehicle Number Emission Measurements. Aerosol Sci. Technol. 2009, 43 (12), $1164-1173$

(35) Giechaskiel, B.; Maricq, M.; Ntziachristos, L.; Dardiotis, C.; Wang, X.; Axmann, H.; Bergmann, A.; Schindler, W. Review of motor 
vehicle particulate emissions sampling and measurement: From smoke and filter mass to particle number. J. Aerosol Sci. 2014, 67, 48-86.

(36) Myhre, G.; Shindell, D.; Breon, F.-M.; Collins, W.; Fuglestvedt, J.; Huang, J.; Koch, D.; Lamarque, J.-F.; Lee, D.; Mendoza, B.; et al. Anthropogenic and Natural Radiative Forcing. In Climate Change 2013: The Physical Science Basis. Contribution of Working Group I to the Fifth Assessment Report of the Intergovernmental Panel on Climate Change; Stocker, T. F., Qin, D., Plattner, G.-K., Tignor, M., Allen, S. K., Boschung, J., Nauels, A., Xia, Y., Bex, V., Midgley, P. M., Eds.; Cambridge University Press: Cambridge, UK, 2013.

(37) Gélin, P.; Primet, M. Complete oxidation of methane at low temperature over noble metal based catalysts: a review. Appl. Catal., B 2002, 39 (1), 1-37.

(38) Dronniou, N.; Kashdan, J.; Lecointe, B.; Sauve, K.; Soleri, D. Optical Investigation of Dual-fuel CNG/Diesel Combustion Strategies to Reduce CO 2 Emissions. SAE Int. J. Engines 2014, 7 (2), 873-887.

(39) Cargnello, M.; Delgado Jaén, J. J.; Hernández Garrido, J. C.; Bakhmutsky, K.; Montini, T.; Calvino Gámez, J. J.; Gorte, R. J.; Fornasiero, P. Exceptional activity for methane combustion over modular Pd@CeO2 subunits on functionalized Al2O3. Science 2012, 337 (6095), 713-717.

(40) Papagiannakis, R. G.; Hountalas, D. T. Experimental investigation concerning the effect of natural gas percentage on performance and emissions of a DI dual fuel diesel engine. Appl. Therm. Eng. 2003, 23 (3), 353-365.

(41) Koebel, M.; Elsener, M.; Kleemann, M. Urea-SCR: a promising technique to reduce $\mathrm{NOx}$ emissions from automotive diesel engines. Catal. Today 2000, 59 (3-4), 335-345.

(42) Devadas, M.; Krocher, O.; Elsener, M.; Wokaun, A.; Soger, N.; Pfeifer, M.; Demel, Y.; Mussmass, L. Influence of NO2 on the selective catalytic reduction of NO with ammonia over Fe-ZSM5. Appl. Catal., B 2006, 67 (3-4), 187-196.

(43) Madia, G.; Koebel, M.; Elsener, M.; Wokaun, A. Side Reactions in the Selective Catalytic Reduction of NO $\mathrm{x}$ with Various NO 2 Fractions. Ind. Eng. Chem. Res. 2002, 41 (16), 4008-4015.

(44) Grossale, A.; Nova, I.; Tronconi, E.; Chatterjee, D.; Weibel, M. The chemistry of the NO/NO2-NH3 "fast" SCR reaction over FeZSM5 investigated by transient reaction analysis. J. Catal. 2008, 256 (2), 312-322.

(45) Grossale, A.; Nova, I.; Tronconi, E.; Chatterjee, D.; Weibel, M. NH3-NO/NO2 SCR for Diesel Exhausts Aftertreatment: Reactivity, Mechanism and Kinetic Modelling of Commercial $\mathrm{Fe}-$ and $\mathrm{Cu}-$ Promoted Zeolite Catalysts. Top. Catal. 2009, 52 (13-20), 18371841. 